\title{
Chemical Composition and Insecticide Activity of Essential Oil of Mesosphaerum suaveolens Against
}

\author{
Nauphoeta cinerea
}

\author{
José Weverton Almeida Bezerra (Corresponding Author) \\ Regional University of Cariri - URCA, Crato, CE, Brazil. \\ E-mail: weverton.almeida@urca.com
}

\begin{abstract}
Francisco Alves Grangeiro Neto, Jacques Tavares Pereira Filho
Federal University of Pernambuco - UFPE, Caruaru, PE, Brazil
\end{abstract}

\begin{abstract}
Adrielle Rodrigues Costa, Arycelle Alves de Oliveira, Isabella Hevily Silva Torquato, Natália Barbosa Campos, Talina Guedes Ribeiro, Priscilla Augusta de Sousa Fernandes, Conceiçao Taís de Araújo Pereira, Gledson Ferreira Macedo, Raimunda Aureniza Feitosa, Xenia Germana Rodovalho de Alencar, João Cruz Neto, Ma Aparecida Barbosa Ferreira Gonçalo, Maria Ivaneide Rocha Regional University of Cariri - URCA, Crato, CE, Brazil
\end{abstract}

Received: Nov. 3, 2019

doi:10.5296/jas.v8i2.15737
Accepted: Nov. 17, 2019 Published: Jan. 20, 2019

URL: https://doi.org/10.5296/jas.v8i2.15737

\begin{abstract}
Essential oils are compounds produced by secondary plant metabolites and are found in leaf trichomes, moreover, they are characteristic because they present strong odors and present biological activities. Thus, the objective of this work was to evaluate the insecticidal action of Mesosphaerum suaveolens essential oil against nymphs of Nauphoeta cinerea as well as to characterize the chemical constituents present in it. The EO was extracted by means of hydrodistillation and its chemical characterization was done by Gas Chromatography coupled to Mass Spectrometry (GC/MS). For the biological assay against cockroaches, nymphs of 20 days old were selected for which they were submitted to different concentrations (50 - 1000 $\mu \mathrm{g} / \mathrm{mL}$ oil per air) and mortality was evaluated over 48 hours of EO exposure. As a positive
\end{abstract}


control, ethanol $\left(\mathrm{C}_{2} \mathrm{H}_{6} \mathrm{O}\right)$ was used. Have been identified 44 compounds in EO, with $\beta$-Caryophyllene (18.57\%), sabinene (15.94\%) and spatulenol (11.09\%) being the major compounds of EO. This showed no activity against the nymphs at any of the concentrations, whereas the positive control caused mortality at all concentrations tested. Thus, the essential oil of $M$. suaveolens does not present insecticidal properties in low concentrations against the cockroach.

Keywords: Hyptis suaveolens, lamiaceae, cockroach, terpenes

\section{Introduction}

Essential oils are compounds produced by secondary plant metabolites and are found in leaf trichomes, moreover, they are characteristic because they present strong odors and present biological activities (Bezerra et al., 2017). Usually they are mainly composed of mono and sesquiterpenes, however it is common to find other types of terpenes such as diterpenes (Bezerra et al., 2018). Among the biological activities, the main ones are antimicrobial, larvicidal, allelopathic and insecticidal actions (Costa et al., 2017).

Regarding the insecticidal activity, some plants developed chemical constituents with repellent and/or insecticidal properties during the evolution, so that insects did not interfere in the ecological succession of the species, mainly annual species, which are more susceptible4. Among the annual species with insecticidal potential is Mesosphaerum suaveolens (L.) Kuntze, belonging to Lamiaceae, a botanical family rich in volatile terpenes (Bezerra et al., 2017; Harley, 2016).

This species is popularly known as "bamburral" and "lavender-brava" and has been shown to have insecticidal potential against Drosophila melanogaster (Bezerra et al., 2017), Sitophilus zeamais, Acanthscelides obtectus (Abere; Oguwike; Sumaila, 2016) and Anopheles gambiae (Ivoke; Okafor; Owoicho, 2017). In this way, the species exhibits insecticidal properties that can substitute synthetic products, since they present toxicity to non-target organisms (Zemolin et al., 2014).

In addition to diptera and insects of the order Coleoptera, organisms of the order Blattodea, which are included cockroaches, cause serious economic damages to the feeding sectors. So these insects must be controlled in order not to cause damage. As a model in insecticide studies for this order, the cockroach Nauphoeta cinerea has been worked. This species has several advantages for toxicological studies, since they include an easy handling, a rapid proliferation and growth and it is exempt from the ethics committee (Rodrigues et al., 2013; Rugg; Rose, 1984).

Thus, the objective of this work was to evaluate the insecticidal action of $M$. suaveolens essential oil against nymphs of $N$. cinerea as well as to characterize the chemical constituents present in it. 


\section{$\triangle 1$ Macrothink}

\section{Material and Methods}

\subsection{Plant Material}

As for the leaves of M. suaveolens, these were collected in the morning (09:00 hrs) in 2015 under coordinates of Lat: $-6^{\circ} 14^{\prime} 22.40 "$ " Long: $-39^{\circ} 16^{\prime} 14.29^{\prime \prime}$ and altitude of $193 \mathrm{~m}$ of altitude (Figure 1). Fertile branches were treated according to the collection procedures, and later deposited in the same herbarium, under voucher \#12.104.

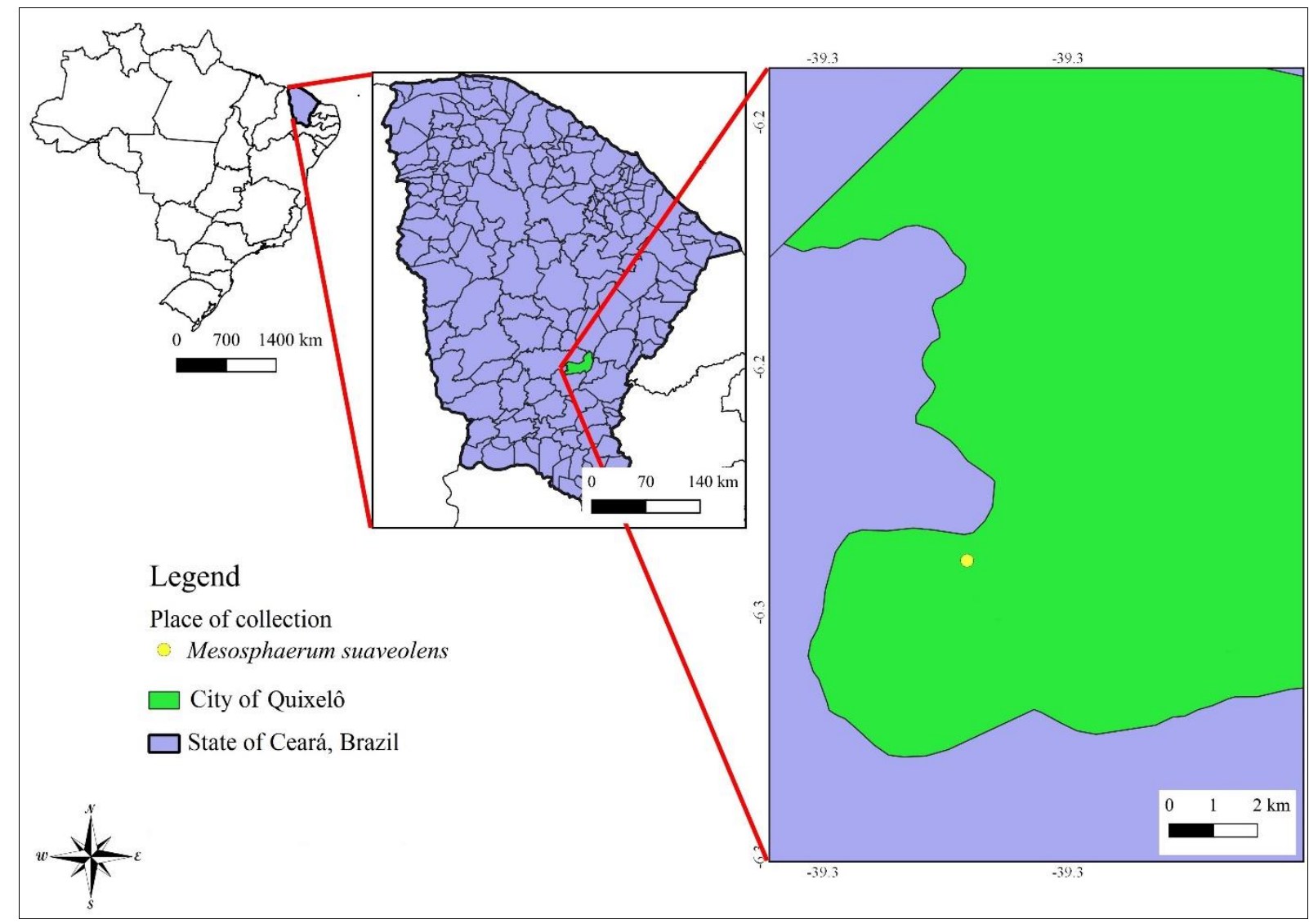

Figure 1. Map of the collection site of the species under study

\subsection{Extraction of Essential Oil}

The essential oil of $M$. suaveolens was extracted from dried leaves, submitted to hydrodistillation in Clevenger apparatus. After collection, the leaves were crushed into small pieces $(150 \mathrm{~g})$ and filled into a $1 \mathrm{~L}$ volumetric flask, where $2 \mathrm{~L}$ of distilled water was added. The flask was coupled to the Clevenger apparatus under the heating mantle and the temperature adjustment was carried out until the water boiled. After boiling, the $2 \mathrm{~h}$ time of the extraction cycle was started. At the end of each extractive cycle, the oil contained in the apparatus was collected with the aid of a pipette and stored in amber and refrigerated bottles. After extraction, sodium sulphate was used to remove the aqueous phase present in the essential oil (Bezerra et al., 2017; Matos, 2009). 


\subsection{Gas Chromatography (GC-FID)}

The gas chromatography (GC) analyses was performed with Agilent Technologies 6890N GC-FID system, equipped with DB-5 capillary column $(30 \mathrm{~m} \times 0.32 \mathrm{~mm} ; 0.50 \mu \mathrm{m})$ and connected to an FID detector. The thermal programmer was $60{ }^{\circ} \mathrm{C}(1 \mathrm{~min})$ to $180{ }^{\circ} \mathrm{C}$ at $3{ }^{\circ} \mathrm{C} / \mathrm{min}$; injector temperature $220{ }^{\circ} \mathrm{C}$; detector temperature $220{ }^{\circ} \mathrm{C}$; split ratio $1: 10$; carrier gas Helium; flow rate: $1.0 \mathrm{~mL} / \mathrm{min}$. The volume injected $1 \mu \mathrm{L}$ diluted in chloroform $(1: 10)$. Two replicates of samples were processed in the same way. Component relative concentrations were calculated based on GC peak areas without using correction factors (Boligon; Feltrin; Athayde, 2013).

\subsection{Gas Chromatography-Mass Spectrometry (GC-MS)}

GC-MS analyses were performed on a Agilent Technologies AutoSystem XL GC-MS system operating in the EI mode at $70 \mathrm{eV}$, equipped with a split/splitless injector $\left(220^{\circ} \mathrm{C}\right)$. The transfer line temperature was $220{ }^{\circ} \mathrm{C}$. Helium was used as carrier gas $(1.0 \mathrm{~mL} / \mathrm{min})$ and the capillary columns used were an HP 5MS (30 m x $0.35 \mathrm{~mm}$; film thickness $0.50 \mu \mathrm{m})$ and an HP Innowax (30 $\mathrm{m} \times 0.32 \mathrm{~mm}$ i.d., film thickness $0.50 \mu \mathrm{m})$. The temperature programmer was the same as that used for the GC analyses. The injected volume was $1 \mu \mathrm{L}$ of the essential oil diluted in chloroform (1:10).

\subsection{Identification of the Components}

Identification of the constituents was performed on the basis of retention index (RI), determined with reference of the homologous series of n-alkanes, $\mathrm{C}_{7}-\mathrm{C}_{30}$, under identical experimental conditions, comparing with the mass spectra library search (NIST and Wiley), and with the mass spectra literature date Adams (Adams, 1995). The relative amounts of individual components were calculated based on the CG peak area (FID response).

\subsection{Inventory and Creation of Nauphoeta Cinerea}

The cockroaches, $N$. cinerea were obtained from the Federal University of Santa Maria UFSM provided by Professor Dr. João Batista Teixeira da Rocha. They were created and maintained at the Laboratory of Microscopy - LABOMIC, of the Regional University of Cariri - URCA, under temperature conditions of $25 \pm 5{ }^{\circ} \mathrm{C}$ and relative humidity of $50 \%$. The diet of adult cockroaches and nymphs consisted of dog food and water at will.

\subsection{Insecticidal Test Against Nauphoeta Cinerea}

For the insecticidal assay the essential oil of L. montevidensis was contacted with filter paper and then attached to the $330 \mathrm{~mL}$ volume flask lid. Subsequently, 40 nymphs per group with 20 days of age were submitted to different concentrations of essential oil (50 - $1000 \mu \mathrm{g} / \mathrm{mL}$ oil per air) and mortality was evaluated over 24 hours of OE exposure. The assay was accompanied by a negative control and a positive control. In this case, for the positive control ethanol $\left(\mathrm{C}_{2} \mathrm{H}_{6} \mathrm{O}\right)$ was used, since it is toxic and volatile, the ethanol was used at the same concentration. The protocol followed the methodology (Bezerra et al., 2017). 


\subsection{Statistical Analysis}

Statistical analyzes were performed using the software GraphPad Prism 6, using One-Way Variance Analysis (ANOVA), followed by the Tukey test at $95 \%$ reliability $(p<0.0001)$.

\section{Results}

\subsection{Chemical Composition}

According to table 1, the essential oil of $M$. suaveolens presents a heterogeneous chemical composition, since it had a total of 44 components. Among these, the main constituents are $\beta$-Caryophyllene (18.57\%), the sabinene (15.94\%) and spathulenol (11.09\%), which together account for $45.65 \%$ of the composition.

Table 1. Composition of Mesosphaerum suaveolens essential oil

\begin{tabular}{|c|c|c|c|}
\hline \multirow{2}{*}{ Compounds } & \multirow{2}{*}{$\mathbf{R} \mathbf{I}^{\mathbf{a}}$} & \multirow{2}{*}{$\mathbf{R I}^{\mathbf{b}}$} & \multirow{2}{*}{$\frac{\text { oil }}{\%}$} \\
\hline & & & \\
\hline$\alpha$-Thujene & 989 & 931 & 1.09 \\
\hline$\alpha$-Pinene & 940 & 939 & 0.85 \\
\hline Sabinene & 976 & 976 & 15.94 \\
\hline$\beta$-Pinene & 980 & 980 & 2.11 \\
\hline Myrcene & 994 & 991 & 0.26 \\
\hline$\delta$-2-Carene & 999 & 1001 & 0.49 \\
\hline$\alpha$-Phellandrene & 1006 & 1005 & 1.38 \\
\hline$\alpha$-Terpinene & 1019 & 1018 & 1.05 \\
\hline p-Cymene & 1030 & 1029 & 0.76 \\
\hline Limonene & 1031 & 1031 & 5.19 \\
\hline 1-8-Cineole & 1037 & 1033 & 3.04 \\
\hline (Z)- $\beta$-Ocimene & 1041 & 1040 & 0.07 \\
\hline (E)- $\beta$-Ocimene & 1055 & 1050 & 0.12 \\
\hline$\gamma$-Terpinene & 1060 & 1061 & 2.97 \\
\hline cis-Sabinene hydrate & 1068 & 1068 & 0.61 \\
\hline Linalool & 1095 & 1098 & 0.43 \\
\hline cis-p-Menth-2-en-1-ol & 1123 & 1121 & 0.28 \\
\hline t-Sabinol & 1139 & 1140 & 0.15 \\
\hline 4-Tepineol & 1178 & 1177 & 6.82 \\
\hline p-Cymen-8-ol & 1183 & 1183 & 0.23 \\
\hline$\alpha$-Terpineol & 1191 & 1189 & 0.94 \\
\hline$\delta$-Elemene & 1335 & 1338 & 1.17 \\
\hline$\alpha$-Copaene & 1377 & 1376 & 0.09 \\
\hline$\beta$-Elemene & 1390 & 1391 & 0.78 \\
\hline$\beta$-Cedrene & 1416 & 1417 & 0.14 \\
\hline
\end{tabular}


$\beta$-Caryophyllene

$\beta$-Gurjunene

$\gamma$-elemene

aromadendrene

$\alpha$-humelene

alloaromadendrene

$\gamma$-muurolene

germacreno D

$\beta$-selinene

Bicyclogermacrene

$\gamma$-cadinene

$\delta$-cadidene

germacrene B

spathulenol

caryophyllene oxide

globulol

Cubenol

$\beta$-eudesmol

$\alpha$-Cadinol
1421

1433

1435

1439

1453

1461

1477

1481

1486

1501

1512

1525

1559

1576

1580

1582

1641

1649

1656
1418

1432

1433

1439

1454

1462

1477

1480

1485

1488

1513

1520

1556

1576

1581

1583

1642

1649

1653
18.57

0.23

1.44

0.32

1.17

0.40

0.28

5.21

0.89

7.52

0.36

0.09

0.27

11.09

3.18

0.62

1.07

0.13

0.45

Total identified $(\%)$

99.97

Relative proportions of the essential oil constituents were expressed as percentages.

$\mathrm{RI}^{\mathrm{a}}$ Retention indices experimental (based on homologous series of $\mathrm{n}$-alkane $\mathrm{C}_{7}-\mathrm{C}_{30}$ ).

$\mathrm{RI}^{\mathrm{b}}$ Retention indices from literature (Adams, 2007).

\subsection{Insecticide Activity Against Nauphoeta Cinerea}

As shown in Figure 2, contrary to the hypothesis of this work, the essential oil of $M$. suaveolens did not present insecticidal action in 24 hours against the nymphs of $N$. cinerea. There was only mortality in the positive control group from the lowest concentration (50 $\mu \mathrm{g} / \mathrm{mL})$. 


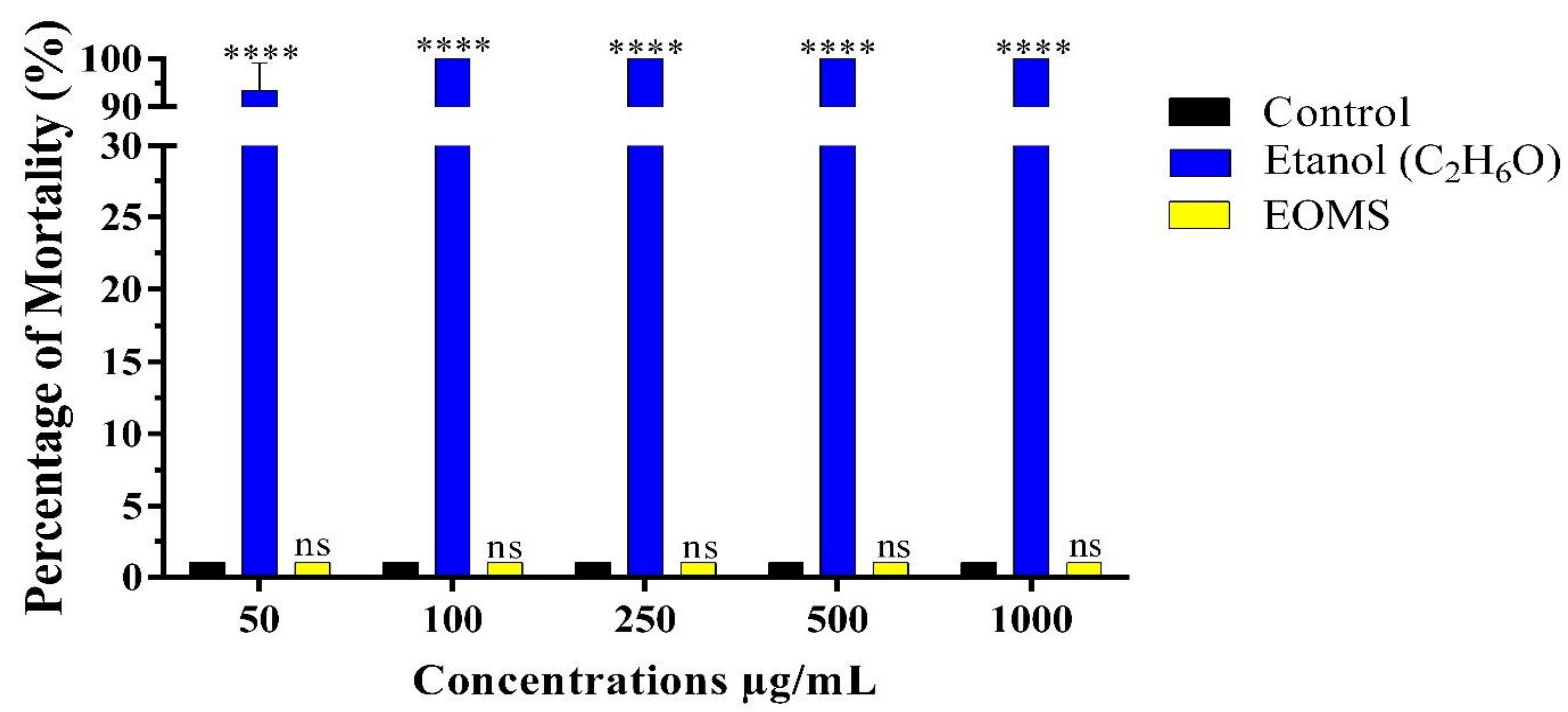

Figure 2. Percentage of mortality of nymphs of Nauphoeta cinerea nymphs submitted to the essential oil of Mesosphaerum suaveolens (EOMS) at various concentrations

\section{Discussion}

Phytochemically, the essential oil of $M$. suaveolens presents variations of study for study, this is common for this species since it has a great distribution throughout the terrestrial globe, consequently the environments that this species is present have their characteristics (Mishra et al., 2011). In this study the collection was carried out in the Caatinga, a seasonally dry tropical forest of Northeast Brazil, and showed as main components $\beta$-Caryophyllene (18.57\%). In the study (Wangrawa et al., 2018) the major compound is 1.8 Cineole (26.4\%), and the species was collected in the African continent in a Sudanian Savanna area which is a large tropical savannah belt that runs to the east and west across the African continent, from the Atlantic Ocean to the west to the western lowlands in the east (Savadogo et al., 2007).

Generally, the major compound determines the biological property of the essential oil, and in this study the main constituent was $\beta$-Caryophyllene $\left(\mathrm{C}_{15} \mathrm{H}_{24}\right)$, this is a bicyclic sesquiterpene present in other essential oils such as Syzygium aromaticum (L.) Merr (Prasha; Locke; Evans, 2006) and Cannabis sativa L. (Wangrawa et al., 2018). This terpene is a sweet and dry tasting compound that can be found in a number of food items such as allspice, fig, pot marjoram, and roman camomile, which makes $\beta$-caryophyllene a potential biomarker for the consumption of these food products. Biologically, this compound presents some properties as larvicide in Anopheles subpictus, Aedes albopictus and Culex tritaeniorhynchus (Govindarajan et al., 2016).

The oil of the species under study has an insecticidal activity against the fly Drosophila melanogaster justifying that such action can be attributed to a synergistic action of the constituents, since the oil has a heterogeneous composition (Bezerra et al., 2017). While in our study there was no insecticidal action, this fact can be justified because they are different biological organisms. 
Usually the essential oils present antioxidant actions, however some research shows that at the cellular level in eukaryotic organisms, oils can act as pro-oxidants, affecting cell membranes and organelles like mitochondria. Furthermore, depending on the concentration, they may exhibit cytotoxic effects, thus these oils can be used in the formulation of bioinsecticide (Bakkali et al., 2008).

\section{Conclusion}

In our study, the oil of $M$. suaveolens did not present an insecticidal action against the cockroach, however the oil may present an insecticidal action in higher concentrations.

\section{References}

Abere, T. A., Oguwike, E., \& Sumaila, M. (2016) Pharmacognostic standardization and insecticidal activity of the leaves of Hyptis suaveolens (L.) Poit (Lamiaceae). Journal of Pharmacy \& Bioresources, 13(2), 163-170. https://doi.org/10.4314/jpb.v13i2.12

Adams, R. P. (1995). Identification of essential oil components by Gas Chromatography/Mass spectroscopy. Allured Publishing Corporation: Illinois USA, p. 456.

Bakkali, F., Averbeck. S., Averbeck, D., \& Idaomar, M. (2008). Biological effects of essential oils-a review. Food Chemical Toxicology, 46(2), 446-475. https://doi.org/10.1016/j.fct.2007.09.106

Benelli, G., Flamini, G., Canale, A., Molfetta, I., Cioni, P. L., \& Conti, B. (2012). Repellence of Hyptis suaveolens whole essential oil and major constituents against adults of the granary weevil Sitophilus granarius. Bulletin of Insectology, 65(2), 177-183.

Bezerra, J. W. A., Costa, A. R., Silva, M. A. P., Rocha, M. I., Boligon, A. A., Rocha, J. B. T., ... Kamdem, J. P. (2017). Chemical composition and toxicological evaluation of Hyptis suaveolens (L.) Poiteau (LAMIACEAE) in Drosophila melanogaster and Artemia salina.

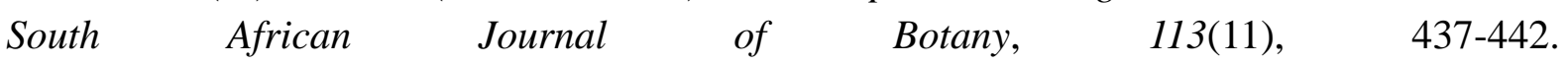
https://doi.org/10.1016/j.sajb.2017.10.003

Bezerra, J. W. A., Santos, M. A. F., Meiado, M. V., Linhares, K. V., Boligon, A. A., Leandro, C. S., ... Silva, M. A. P. (2018). Allelopathy of Aromatic Species on the Germination of Cereus jamacaru DC. subsp. jamacaru (Cactaceae). The Journal of Agricultural Science, 10(11), 337-348. https://doi.org/10.5539/jas.v10n11p337

Boligon, A. A., Feltrin, A. C., \& Athayde, M. L. (2013). Determination of chemical composition, antioxidant and antimicrobial properties of Guzuma ulmifolia essential oil. American Journal of Essential Oils and Natural Products, 1(s/n), 23-27. 10.4172/2167-0412.1000126

Costa, A. R., Lima, S. J., Lima, K. R. R., Rocha, M. I., Barros, L. M., Costa, J. G. M., \& Menezes, I. R. A. (2017). Rhaphiodon echinus (Nees \& Mart.) Schauer: Chemical, toxicological activity and increased antibiotic activity of antifungal drug activity and antibacterial. Microbial Pathogenesis, 280-286. https://doi.org/10.1016/j.micpath.2017.04.001 
Gertsch, J., Pertwee, R. G., \& Di Marzo, V. (2010). Phytocannabinoids beyond the Cannabis plant-do they exist?. British Journal of Pharmacology, 160(3), 523-529. https://doi.org/10.1111/j.1476-5381.2010.00745.x

Govindarajan, M., Rajeswary, M., Hoti, S. L., Bhattacharyya, A., \& Benelli, G. (2016). Eugenol, $\alpha$-pinene and $\beta$-caryophyllene from Plectranthus barbatus essential oil as eco-friendly larvicides against malaria, dengue and Japanese encephalitis mosquito vectors. Parasitology Research, 115(2), 807-815. https://doi.org/10.1007/s00436-015-4809-0

Harley, R. M. (2016). Flora of the cangas of the Serra dos Carajás, Pará, Brasil: Lamiaceae. Rodriguésia, 67(5), 1381-1398. https://doi.org/10.1590/2175-7860201667536

Ivoke, N., Okafor, F. C., \& Owoicho, L. O. (2009). Evaluation of ovicidal and larvicidal effects of leaf extracts of Hyptis suaveolens (L) poit (Lamiaceae) against Anopheles gambiae (Diptera: Anophelidae) complex. Animal Research International, 6(3), 1072-1076. https://doi.org/10.4314/ari.v6i3.55987

Matos, F. J. A. Introdução à Fitoquímica Experimental (2009). Fortaleza: UFC.

Mishra, S. B., Verma, A., Mukerjee, A., \& Vijayakumar, M. (2011). Anti-hyperglycemic activity of leaves extract of Hyptis suaveolens L. Poit in streptozotocin induced diabetic rats. Asian Pacific Journal of Tropical Medicine, 4(9), 689-693. https://doi.org/10.1016/S1995-7645(11)60175-2

Prashar, A., Locke, I. C., \& Evans, C. S. (2006). Cytotoxicity of clove (Syzygium aromaticum) oil and its major components to human skin cells. Cell Proliferation, 39(4), 241-248. https://doi.org/10.1111/j.1365-2184.2006.00384.x

Rodrigues, N. R., Nunes, M. E. M., Silva, D. G. C., Zemolin, A. P. P., Meinerz, D. F., Cruz, L. C., \& Franco JL (2013). Is the lobster cockroach Nauphoeta cinerea a valuable model for evaluating mercury induced oxidative stress? Chemosphere, 92(9), 1177-1182. https://doi.org/10.1016/j.chemosphere.2013.01.084

Rugg, D., \& Rose, H. A. (1984). Reproductive biology of some Australian cockroaches (Blattodea: Blaberidae). Australian Journal of Entomology, 23(2), 113-117. https://doi.org/10.1111/j.1440-6055.1984.tb01922.x

Savadogo, P., Tigabu, M., Sawadogo, L., \& Odén, P. C. (2007). Woody species composition, structure and diversity of vegetation patches of a Sudanian savanna in Burkina Faso. Bois et Forets des Tropiques, 294(4), 5-20.

Wangrawa, D. W., Badolo, A., Ilboudo, Z., Guelbéogo, W. M., Kiendrébeogo, M., Nébié, R. C. H., \& Sanon, A. (2018). Insecticidal Activity of Local Plants Essential Oils Against Laboratory and Field Strains of Anopheles gambiae sl (Diptera: Culicidae) From Burkina Faso. Journal of Economic Entomology, 111(6), 2844-2853.

https://doi.org/10.1093/jee/toy276

Zemolin, A. P. P., Cruz, L. C., Paula, M. T., Pereira, B. K., Albuquerque, M. P., Victoria, F. C., \& Franco, J. L. (2014). Toxicity induced by Prasiola crispa to fruit fly Drosophila 


\section{Macrothink}

Journal of Agricultural Studies

ISSN 2166-0379 2020, Vol. 8, No. 2

melanogaster and cockroach Nauphoeta cinerea: evidence for Bioinsecticide action. Journal of Toxicology and Environmental Health, 77(3), 115-124.

https://doi.org/10.1080/15287394.2014.866927

\section{Copyright Disclaimer}

Copyright for this article is retained by the author(s), with first publication rights granted to the journal.

This is an open-access article distributed under the terms and conditions of the Creative Commons Attribution license (http://creativecommons.org/licenses/by/4.0/). 